The Geneva Papers on Risk and Insurance, 18 (No. 67, April 1993), 139-143

\title{
The Supervision of Financial Conglomerates
}

\author{
by Klaus-Wilhelm Knauth * and Hans-Joachim Welzel **
}

\section{Introduction}

The Directives on insurance companies, credit institutions and securities firms, which have already - or are about to - come into force, show that by 1994 the EC Commission will have achieved the essential requirements for the creation of the internal market for the insurance and banking businesses. To put these EC Directives into effect, member states will have to make far-reaching changes to the supervisory legislation governing insurance and banking and involving in turn corresponding adjustments by those companies which are subject to supervisory authorities. Adapting both to the new legislation and in particular to the product innovation and increased competition which is expected to result from the more liberal supervision, will require considerable time and financial expenditure.

Whilst the member states, the supervisory authorities and the institutions they supervise are still fully occupied in implementing these changes, the EC Commission is already considering a new set of regulations. It has taken up the subject of the so called "financial conglomerates", which has been discussed internationally for some time (if not formally at the political level), with the intention of creating a "harmonised" supervisory regime for financial conglomerates. The term financial conglomerates is taken to mean groups of financial institutions from different sectors (banks, insurance companies, investment services firms) which are connected by participations (the extent of which has yet to be defined). The EC Commission has put forward three main reasons for its plans in this area:

- The dangers that risks can be obscured by lack of transparency and by "contagion" through the so-called "double gearing" of the capital and reserves (own funds).

- Distortion of competition between banks and insurance companies.

- The need to simplify the operations of the supervisory bodies.

\footnotetext{
${ }^{*}$ Leiter der Abteilung Kapitalanlagen, Gesamtverband der Deutschen Versicherungswirtschaft e. V., Bonn. Bonn.

** Stellv. Verbandsdirektor, Gesamtverband der Deutschen Versicherungswirtschaft e.V.,
} 
The EC Commission would be well advised to investigate the validity of these assumptions in depth and the following observations are intended to contribute to such consideration. ${ }^{1}$

The EC Commission has not been alone in calling, simplistically, for the creation of group solvency regulations for insurers based on those applicable to the banks. This is all the more surprising as the present solvency regulations governing banks and insurance companies in the Common Market are clearly differentiated, in our opinion for good reasons. The EC Directives for insurance companies, including the recently adopted "3rd. Generation Directives" 2, apply exclusively to each individual firm whereas the Directives governing the solvency of banks also relate to groups of companies. To depart from this approach by aligning the solvency requirements, i.e. the security margins, for insurance companies with those governing the banks would result in an inadmissible equal treatment of unequal situations and would not take into account the fact that banks and insurance companies have fundamentally different exposures to risk because of the different natures of their business.

\section{2. “Double gearing"}

For banks, the main risk to be faced is the credit risk. This depends on the state of the economy and, in the event of recession, affects nearly all the credit institutions in a banking group simultaneously. Accordingly, there is a high degree of positive correlation between the business risks and the participation risks. In such conditions, a bank can not cover heavy losses sustained in its own credit operations by disposing of participations in other banks as these will have their own losses to bear which will substantially impair their inherent value. Losses arising on credit business and losses in the value of participations create a double burden on the parent bank. It therefore seems desirable to guard against this double burden by the provision of appropriate capital resources.

For insurance companies, the technical insurance risk predominates, the risk being that actual claims may exceed those anticipated. In contrast to the banking sector, the business risk only affects parent and subsidiary companies concurrently in the exceptional event of their underwriting similar risks, (i. e. similar business portfolios). In the insurance sector, the business risks and the participation risks are therefore usually independent of each other. The double burden which threatens a group solely involved in banking is unlikely to affect an insurance group.

Furthermore, the risks underwritten by life and general insurers are practically independent of the banks credit risks. This can be illustrated by taking as an example the

I See also Dieter Farny: Solvabilität und Solvabilitätspolitik der Versicherungsunternehmen (Solvency and Solvency policy of insurers). In: Zeitschrift für die gesamte Versicherungswissenschaft. Vol. 73, 1984, pp. 35-67; Walter Karten: Do shares in other insurance companies reduce the solvency margin of an insurer? In: Risk, Information and Insurance. Ed. Henri Loubergé. Boston/Dordrecht/ London 1990, pp. 257-267; Norbert Konrath: Solvabilitätsregeln auf dem Prüfstand (Solvency regulations on the testbed). In: Versicherungswirtschaft, 34th year, 1979, pp. 1509-1514.

2 Directive 92/49/EEC. Council Directive of 18 June 1992, on the co-ordination of laws, regulations and administrative provisions relating to direct insurance other than life assurance and amending Directives 73/239/EEC and 88/357/EEC (Third non-life insurance Directive) OJ of EC No. L 228 of 11 August 1992, pp. 1-23; Third Council Directive on the co-ordination of laws, regulations and administrative provisions relating to direct life assurance and amending Directives 79/267/EEC and 90/619/EEC (Adopted by the Internal Market Council on 10 November 1992). 
repercussions of the insolvency of an industrial firm on a financial conglomerate consisting of a commercial bank whose client that firm is, the bank's subsidiary mortgage bank and a subsidiary general insurance company. If the losses are serious, the business losses suffered by the commercial bank and by its mortgage subsidiary will be exacerbated by the reduction in the value of the participation in the mortgage bank.

In contrast, the general insurance company only suffers a reduction in its premium income, with a corresponding reduction in the risk exposure. If a financial conglomerate also includes a life insurer, then those insured risks (e. g. death, permanent health) are neither positively correlated to the risks of the general insurer nor to the bank's credit risk. Because these risks are not interdependent no specific "conglomerate" risk arises. Double gearing does not take place.

In contrast to the banks, insurance companies do not accept short term deposits, so that the precondition for the risk of contagion both within the Group and beyond does not arise. Similarly insurance companies do not provide loans for working capital or other short-term credit. In addition the regulations of the law on Insurance Supervision, which require diversification and spreading of investments, prevent a dangerous concentration in any one type of investment.

The exposure to concurrent risks by associated banks, which is the main factor underlying the consolidation requirements for credit institutions, is therefore generally not relevant either in the insurance sector or in Bank and Insurance conglomerates.

The oft-quoted "multiple gearing" of capital as such does not require supervision on a consolidated basis; nevertheless the multiple gearing of capital resources apparent in financial conglomerates would seem to be the main reason for the introduction of supervision on a consolidated basis. This has obviously been influenced by the concept of "credit pyramids" found in banking which was the reason for supervision on a consolidated basis. However, this viewpoint ignores the fact that - as has been shown above - the banks' credit risk is completely independent of the insurers' technical risk and therefore consolidation is not necessary from the point of view of risk. Credit pyramids can hardly be built up through participations of banks in insurance companies.

Comparisons drawn between these credit pyramids and the effect of "Premium Pyramids" in insurance groups are practically irrelevant in terms of the risk aspects which are decisive in this respect, because the concurrent risks found in the credit business, where the business and participation risks can be simultaneously incurred, only arise in the insurance business in those rare instances where the business portfolios are similar (for instance, a participation by one life insurance company in another life insurance company). However, to adopt consolidation simply to deal with these exceptional situations, seems to us to be inappropriate having regard to the risk involved, questionable in terms of company law (for example a lack of responsibility for intervention which would conflict with the principle of business specialisation) and disproportionate in terms of the administrative principle of relevancy.

Furthermore, the capital resources are only one link - though an important one - in a chain of security provisions of insurance companies. The insurance industry has developed a wide range of diverse and effective instruments to protect the rights of the policyholders, in which the capital resources do not play a dominant role. This protection is primarily achieved by the technical provisions for insurance liabilities, by reinsurance and separation 
of the different classes of business (specialisation); in addition the security of the investments is ensured by detailed regulations concerning their diversification and spreading.

This successful system has proved to be very effective against the danger of insolvency in the case of insurance companies in Germany. On the other hand, the system regulating the banks, which is primarily based on their capital and reserves (own funds), has not prevented insolvencies from occurring in Germany. In the United States, where there have been over a thousand problem cases in the banking sector between 1985 and 1991, the Securities and Exchange Commission has now even called the value of such a system into question.

The foregoing arguments can no doubt be discussed in greater depth. However, in our opinion they clearly indicate that the introduction of "group solvency" for insurance groups and overall solvency for financial conglomerates - along the lines of the banking system would be superfluous and technically unsound. If one or the other were to lead to increased capital requirements, it would in the final analysis be the customers of the associated companies who would have to pay for this supposed increase in the security standard through higher prices. If a general security provision was levied within the financial conglomerate to cover this, the overall security would not, as intended, increase, but decrease.

\section{Distortion of competition}

Put simply, this argument states that banks and insurance companies are increasingly competing with each other, with a range of products particularly directed to the investment of savings. This argument does not apply either to the entire area of general insurance or to sickness insurance; at most it concerns only limited areas of life insurance business. Apart from this, it would be illusory to suppose that competition on an equal footing would be achieved solely by creating identical solvency regulations for banks and insurance companies. Large areas of the law would be affected. Over and above that, it is an open question whether identical treatment would even be desirable, given the differences in business aims.

There is no need here, however, to consider the arguments relating to competition in greater detail, as the EC Commission fortunately does not yet seem to have established an opinion. In fact it has only recently announced an EC-wide study on whether significant distortions between credit institutions and insurance companies exist at all.

\section{Simplification of supervision}

The simplified argument here is that financial conglomerates can most easily be supervised by means of unified solvency regulations, possibly even by one integrated supervisory authority, on the Scandinavian model. That option, namely the integration of financial supervision under a single authority, does not (any longer) appear to be a short, or even medium term objective of the EC Commission, at least at the present time, and difficulties recently experienced by Scandinavian financial conglomerates give no encouragement to go down this route.

The question remains how supervision of financial conglomerates by means of the present systems of separate authorities for banks and insurers can be made easier. As explained above, there is nothing to be gained by simplifying the system through inappropriate requirements for solvency measurement. On the other hand, the needs of the respective supervisory authorities for information about the banking or insurance arms of financial 
conglomerates must certainly be recognised. Increased co-operation between banking and insurance supervisory authorities would suffice to secure the necessary information, for instance on the lines of the now established co-operation in the EC between the national supervisory authorities for credit business and for the insurance industry. The conditions necessary for this could be achieved by amendments to the Third Non-Life Insurance and the Third Life Insurance Directives, and the Second Banking Co-ordination Directive. Such a procedure would meet the principle of minimum legislation and would accord with the currently much vaunted principle of subsidiarity. 